\title{
Methodology for the Efficiency Evaluation of the Municipal Environmental Protection Expenditure
}

\author{
Jana Soukopová and Michal Struk \\ Masaryk University, Faculty of Economics and Administration, Department of Public \\ Economics, Lipová 41a, 60200 Brno, Czech Republic \\ soukopova@econ.muni.cz, struk@mail.muni.cz
}

\begin{abstract}
This paper deals with an efficiency of current municipal expenditure on environmental protection and suggests a methodology for assessing this efficiency. A proposal of methodological procedure for evaluating efficiency of municipal environmental protection expenditure uses multi-criteria evaluation, where a dominant criterion of performance is modified method of Costeffectiveness analysis. It was implemented in open source software. The efficiency in the methodology is intended in terms of $3 \mathrm{E}$ methodology Economy, Efficiency and Effectiveness, together with the methodology of sustainable development - social, environmental and economic part of sustainable development. This procedure is applied to a set of environmental protection expenditure data that come from the representative sample of municipalities in areas of waste management which were used in a project of the Ministry of Environment of the Czech Republic SP/4i1/54/08 "Analysis of municipal budgets efficiency in relation to the environmental protection".
\end{abstract}

Keywords: methodology, municipal environmental protection expenditure, efficiency, effectiveness, economy, sustainable development.

\section{Introduction}

Environmental protection expenditure is terms for the money that society spends on the environmental protection. Nowadays, the protection of the environment is integrated into all fields of policy with the general objective of reaching sustainable development. Clean air, water and soil, healthy ecosystems and rich biodiversity are vital for human life, and thus it is not surprising that societies devote large sums of money to pollution reduction and preservation of healthy environment.

Consequently is the environmental protection expenditure (EPE) one of the indicators for evaluating the standard of the environmental protection not only at the level of municipalities and governments, but also for the comparison of environmental protection in the world.

EPE is the money spent on activities directly aimed at the prevention, reduction and elimination of pollution resulting from the production or consumption of goods and services [1]. These are, for example, waste disposal activities and wastewater treatment activities, as well as activities aimed at noise abatement and air pollution control. Environmental protection expenditure does not directly take into account the 
expenditure for the sustainable management of natural resources. All economic sectors, businesses in agriculture, industry and services as well as the public sector and households spend some money on reducing, preventing and eliminating their pressures on the environment.

For instance, both businesses and households pay for safe waste disposal, spend money on mitigation of the polluting effects of production processes and governments pay for provision of environmental public goods, such as the basic levels of sanitation required to safeguard health.

Governments subsidize environmentally beneficial activities and use public funds in order to make it easier for subjects to borrow money on the financial markets for environmental projects. To be more specific, this is done through measures such as risk sharing, credit enhancement or subsidies that lower the costs of borrowing for communities that cannot afford to carry full costs of investments into environmental projects.

Therefore the main objective of this paper is an evaluation of the efficiency of public expenditure and other financial instruments in the field of environmental protection with focus on particular regions, together with the optimization of incidence of public subsidies for environmental protection on macro and microeconomical level. Further objective is the development of open source software [10] supporting this evaluation.

In the Czech Republic the important part is identification of factors that influence absorption capacity of individual regions and setting of indicators for the evaluation of their effectiveness.

\section{Public Environmental Protection Expenditure}

Public expenditure in the field of environmental protection represents important part of total public expenditure and, thanks to the active policy of European Union and expenditures from its structural funds, its sum probably won't decrease notably even in the time of financial crisis.

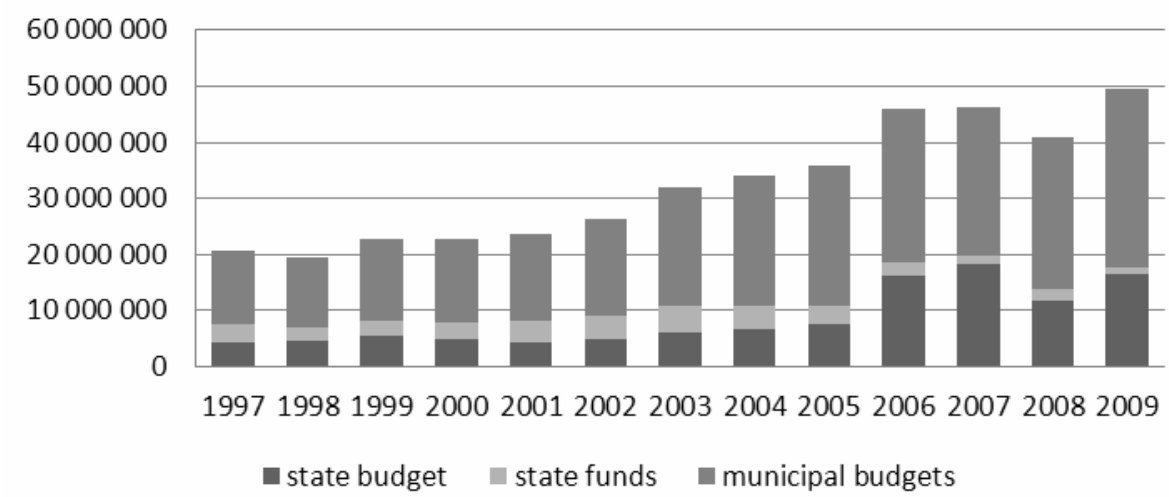

Fig. 1. Environmental expenditures of public budgets in the Czech Republic (in thousands CZK), 1997-2009 [2] 
Figure 1 shows the progression of public expenditure since 1997. Apart from legislative and regulatory tasks, the public sector monitors environmental performance, provides grants and subsidies to encourage environmentally sensitive behaviour and funds research and development activities. In the Czech Republic public administrations, for example municipalities, can also provide environmental protection services, such as waste management or wastewater treatment, directly. These services are generally provided by public corporations, whose activities differ from other governmental administrative tasks.

In the Fig. 1 we can see that throughout the time municipal expenditure made always more than $50 \%$ of total environmental public expenditure.

Environmental expenditure is divided in the budget structure according to the Classification of Environmental Protection Activities and Expenditure (CEPA 2000) into several categories: protection of ambient air and climate; wastewater management; waste management; protection and remediation of soil, groundwater and surface water; noise and vibration abatement; protection of biodiversity and landscapes; protection against radiation; research and development; and other environmental protection activities [3]. As shown in Fig. 2, largest parts of public environmental protection expenditure are wastewater management expenditure, waste management expenditure and protection of biodiversity landscapes expenditure.

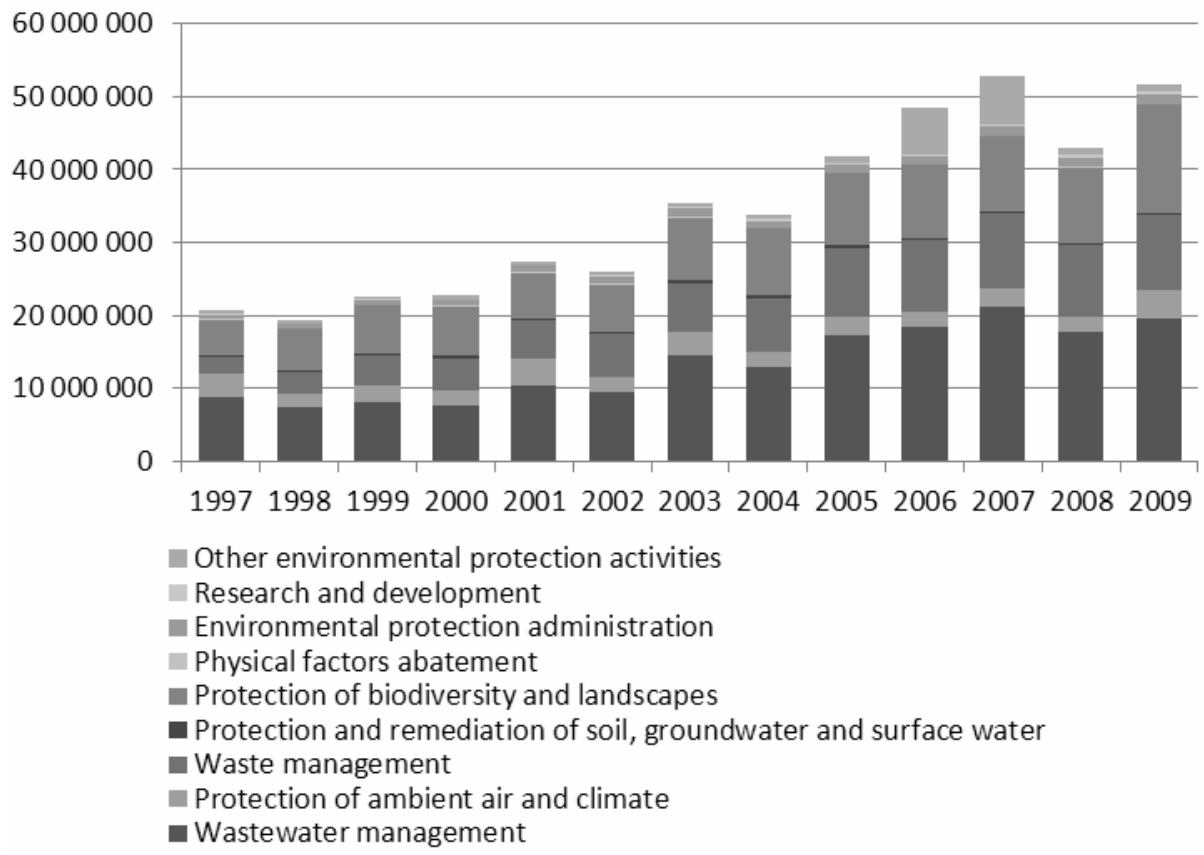

Fig. 2. Municipal environmental expenditures according to CEPA 2000 (in thousands CZK), 1997-2009 [2] 


\section{Methodology of Efficiency Evaluation}

In order to evaluate efficiency of public (environmental) expenditure most authors use the methodology of $3 \mathrm{E}$ - economy, efficiency and effectiveness. According to theory, these terms are perceived like this:

1. Economy - such use of public expenditures, that leads to provision of given objectives with the least amount of resources spent, while keeping up to the corresponding quality of tasks;

2. Efficiency - such use of public expenditures that acquires the greatest possible amount, quality and contribution to the given objectives compared to the amount of resources spent in order to fulfill them ${ }^{1}$.

3. Effectiveness - such use of public expenditures that leads to the greatest possible output respecting desired outcome, which are prerequisite for optimal fulfillment of goals set in advance. Therefore effectiveness means how the produced goods or services (for example waste disposal) fulfill utility (for example clean municipal environment without waste) [4].

When judging all these criteria (economy, efficiency, effectiveness and quality) we can speak of economic efficiency of public expenditure. For the complex view we need to add that sometimes we distinguish between terms technical and allocation efficiency. However, analysis of this concept is beyond the scope of this text. The scheme in Fig. 3 shows the concept of economic efficiency, from which we move on into further analysis and we use it for the construction of methodology for the evaluation of environmental municipal expenditure.

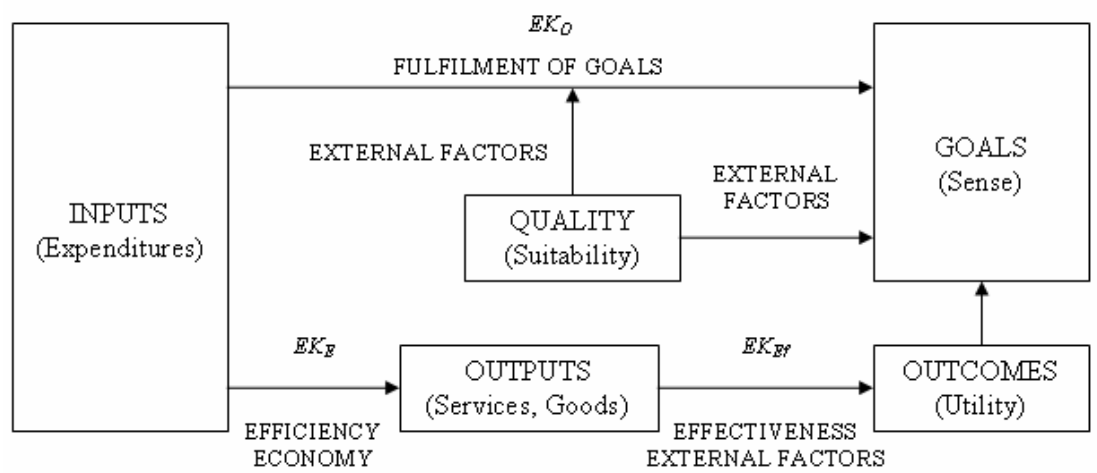

Fig. 3. Conceptual conception of efficiency of public expenditure [4]

\footnotetext{
${ }^{1}$ Economy and efficiency are for purposes of quantification and in respect of usage of methods of economic analysis understood as cost efficiency.
} 


\subsection{Environmental Protection Expenditure Efficiency and Effectiveness}

One of the contemporary problems is how to allocate public expenditure in the field of environment protection more effectively [5]. When considering efficiency and effectiveness, the methodology is based on multi-criteria evaluation of efficiency and effectiveness that is determined by 3 basic pillars of sustainable development. When the methodology was designed, we came out from the evaluation of efficiency and effectiveness in terms of social, environmental and economic points of view (see scheme in Fig. 4).

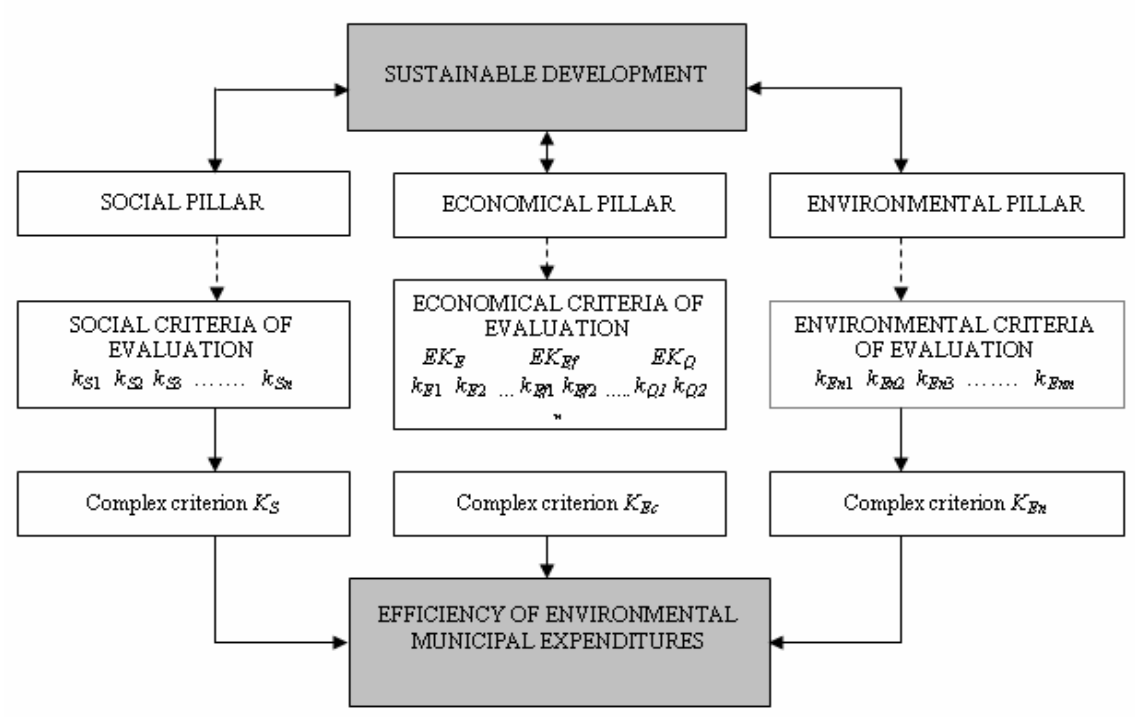

Fig. 4. Scheme of public environmental protection expenditure efficiency evaluation [4]

\subsection{Economic Aspect of Evaluation}

Economic criteria of evaluation come out from the concept of efficiency explained above and include the economical evaluation of efficiency and economy $E K_{E}$, effectiveness $E K_{E f}$ and economic quality $E K_{Q}$, so:

$$
K_{E}=E_{E}+E_{E f}+E_{Q},
$$

where $K_{E}$ is the complex criterion of efficiency evaluation,

$E_{E}$ is the complex criterion of efficiency and economy evaluation (cost efficiency evaluation),

$E_{E f}$ is the complex criterion of effectiveness evaluation,

$E_{Q}$ is the complex criterion of economical quality evaluation (quality of environmental goals). 
More detailed explanation of evaluation methodology according to the given complex criteria follows.

\section{Efficiency evaluation $-E_{E}$}

The most commonly used methods for evaluating efficiency of public expenditure are Cost-minimization Analysis (CMA), Cost-effectiveness Analysis (CEA), Cost-utility Analysis (CUA) and Cost-benefit Analysis (CBA). These methods are in general suitable for the evaluation of efficiency of public expenditure for environmental protection. The only exception is CMA, which only compares amount of expenditures, and therefore will not be considered in further evaluation. Efficiency evaluation of current public budgets expenditures, however, encounters several limitations. This is because current expenditures usually consist of expenditures for public services - services of common interest.

This makes evaluation of expenses using CBA or CUA quite difficult. In case of CBA it is difficult to estimate benefits of these services in terms of money and as for CUA, the situation is even more complicated because there is no suitable methodology for environmental expenditures (however, it exists for health-care and several other) [6]. Therefore, choosing the CEA method appears to be the most appropriate [7, 8], when it comes to the evaluation of efficiency. And for the evaluation of $\mathrm{C} / \mathrm{E}$ we have chosen efficiency indicator $\mathrm{E}$ as a complex criterion created with help of multi-criteria analysis depending on factors influencing expenditure on given environmental service.

Let $K_{E}$ be a set of criteria for the evaluation of quality of environmental public budget expenditures, where $K_{E}=\left(k_{E 1}, k_{E 1}, \ldots, k_{E n}\right)$, then

$$
E=f\left(k_{E 1}, k_{E 2}, \ldots . ., k_{E n}\right) \text {, }
$$

where $k_{E i}$ is the criterion of cost efficiency and economy evaluation,

$n$ is the number of outputs for the environmental protection expenditure.

Then the cost efficiency of given expenditure could be expressed as follows:

$$
C E A=\frac{C}{E} \geq 0 \rightarrow \min
$$

where $C$ is the environmental protection expenditure,

$E$ is the indicator of cost efficiency evaluation.

If $C E A \leq 1$, the expenditure is efficient, if $C E A>1$, the expenditure is inefficient. Because the criterion is minimizing, it needs to be transformed into maximizing one. Therefore for the construction of $E K_{E}$ criterion we will use the following formula:

$$
E_{E}=\frac{1}{C E A}=\frac{E}{C} \geq 0,
$$

where if $E K_{E}>1$, then the expenditure is efficient and $E_{E} \rightarrow \max$. 


\section{Evaluation of the effectiveness $-E_{E f}$}

Let $K_{E f}$ be a set of criteria for the evaluation of effectiveness of environmental municipal expenditures, where $K_{E f}=\left(k_{E f 1}, k_{E f 1}, \ldots, k_{E f \mathrm{n}}\right)$, then

$$
E_{E f}=\sum_{i=1}^{n} w_{i} k_{E f i},
$$

where $\quad k_{E f i}$ is the criterion determining results of given expenditure - percentage fulfillment of the goal No. $i$ (criterion acquires values $0-1$ ),

$n$ is the amount of outcomes (goals) for given environmental expenditure,

$w_{i}$ is the weight of $i$-numbered criterion.

It acquires values $0 \leq E K_{E f} \leq 1 \rightarrow \max$

\section{Evaluation of the quality $-E K_{Q}$}

Let $E K_{Q}$ be a set of criteria for the evaluation of the quality of environmental public budget expenditures, where $E K_{Q}=\left(k_{Q 1}, k_{Q 1}, \ldots, k_{Q \mathrm{n}}\right)$, then

$$
E_{Q}=\sum_{i=1}^{n} w_{i} k_{Q i},
$$

where $k_{Q i}$ is the criterion determining quality - quality of given goal - connection with strategic documents of region or state (in percents) (criterion acquires values $0-1$ ),

$n$ is the amount of outcomes (goals) for given environmental expenditure,

$w_{i}$ is the standardized weight of criterion No. $i$.

\subsection{Environmental Aspect of Evaluation}

Environmental criteria of evaluation come out from indicators of sustainable development in selected field of environmental protection. The complex criterion of the evaluation of efficiency could be from the view of environmental $K_{E n}$ constructed as follows [4]:

$$
K_{E n}=\sum_{i=1}^{n} w_{i} k_{E n i},
$$

where $k_{E n i}$ is the criterion of environmental efficiency, $\quad k_{E n i} \rightarrow \max$

$n$ is the amount of criteria,

$w_{i}$ is the standardized weight of criterion No. $i$.

It acquires values $K_{E n} \geq 0$. If $K_{E n}=0$, the expenditure is fully inefficient. 


\subsection{Social Aspect of Evaluation}

Social criteria of evaluation come out from taking the social aspect of existing expenditure into account. The complex criterion for evaluating efficiency from the social point of view $K_{S}$ could be constructed as follows:

$$
K_{S}=\sum_{i=1}^{n} w_{i} k_{S i}
$$

Where $k_{S i}$ is the social efficiency criterion (in percents),

$n$ is the number of criteria,

$w_{i}$ is the weight of criterion No. $i$.

It acquires values $0 \leq K_{S} \leq 1$ and if $K_{S}=0$, the expenditure is fully inefficient.

\subsection{Summary of the Methodology}

The sequence of this methodology for the evaluation of public environmental protection expenditure can be shown in an algorithm with several phases and steps:

1. Phase - the evaluation of the efficiency:

a. Step 1 - the evaluation of efficiency and economy of expenditure (whether the given goals are being fulfilled with minimal costs, or if the environmental benefits with given costs are maximized). $E_{E}>1 \rightarrow \max$;

b. Step 2 - the evaluation of effectiveness (how municipal environmental expenditure ensures the set goal). $0 \leq E_{E f} \leq 1 \rightarrow \max$;

c. Step 3 - the evaluation of quality (quality of goals is crucial problem of expenditures, that's why we evaluate it too). $0 \leq E_{Q} \leq 1 \rightarrow \max$;

2. Phase - the evaluation of efficiency from environmental view. $K_{E n} \geq 0 \rightarrow \max$.

3. Phase - the evaluation of efficiency from the social view $0 \leq K_{S} \leq 1 \rightarrow \max$;

4. Phase - the evaluation based on importance of individual expenditure in terms of its relation to the whole (each expenditure is multiplied by a weight equal to the proportion of expenditure on total expenditure of the municipality).

This methodology has been programmed as open source software available for all municipalities of the Czech Republic and tested on a sample of 200 South Moravian Region municipalities.

\section{Case Study of the Efficiency Evaluation Using the Methodology}

In the Czech Republic there are 204 municipalities with extended powers (type III municipalities). To test the developed methodology and software, the South Moravian Region was selected. There are 21 type III municipalities in this region. Table 1 shows the list of them. 
Table 1. Municipalities with extended powers in the South Moravian Region

\begin{tabular}{lr}
\hline Municipality & Number of citizens \\
\hline Blansko & 21106 \\
Boskovice & 10965 \\
Brno & 370592 \\
Břeclav & 24242 \\
Bučovice & 6432 \\
Hodonín & 25687 \\
Hustopeče & 5903 \\
Ivančice & 9347 \\
Kuřim & 10492 \\
Kyjov & 11707 \\
Mikulov & 7493 \\
Moravský Krumlov & 5986 \\
Pohořelice & 4521 \\
Rosice & 5504 \\
Slavkov u Brna & 6169 \\
Šlapanice & 6836 \\
Tišnov & 8585 \\
Veselí nad Moravou & 11781 \\
Vyškov & 21875 \\
Znojmo & 34759 \\
Židlochovice & 3472
\end{tabular}

For the following analysis with using developed software we have chosen the sample of municipalities containing only those over 10000 citizens (10 municipalities). Year 2008 was chosen for the analysis. Data on the amount of municipal waste were obtained from the Ministry of the Environment Czech Republic, as shown in Table 2.

\subsection{Evaluation of Economic Aspect of Efficiency and Effectiveness}

Table 2. Information about waste management expenditure and waste amount of type III municipalities in South Moravian Region, year 2008

\begin{tabular}{lcc}
\hline $\begin{array}{l}\text { Type III } \\
\text { municipality }\end{array}$ & $\begin{array}{c}\text { Expenditure on waste management, } \\
\text { thousands CZK, 2008 }\end{array}$ & $\begin{array}{c}\text { Amount of municipal } \\
\text { waste, tons, 2008 }\end{array}$ \\
\hline Blansko & 14962.04 & 5417 \\
Boskovice & 6968.61 & 2441 \\
Brno & 366459.47 & 118663 \\
Břeclav & 18387.23 & 8655 \\
Hodonín & 19773.20 & 9321 \\
Kuřim & 6410.08 & 2662 \\
Kyjov & 7441.25 & 5320 \\
Veselí nad & 7207.84 & 6278 \\
Moravou & 13003.84 & 9659 \\
Vyškov & 30575.97 & 8694 \\
Znojmo & &
\end{tabular}




\section{Economy and efficiency evaluation $-E_{E}$}

In case of municipal waste collection there are several input parameters of software: waste amount, rate for waste manipulation, rate for waste transportation, transportation vehicle's capacity and distance to the processing facility. Costs of collection are then the following:

$$
E=V_{E}=2 * v * s_{d} * \frac{Q}{k_{d}}+m * Q+p * Q
$$

and

$$
E_{E}=\frac{E}{C} \geq 0
$$

where $v$ is distance from the facility (landfill, incinerator) $[\mathrm{km}]$ including the distance in the municipality - $\left(\mathrm{k}_{\mathrm{E} 3}\right)$

$s_{d}$ is rate for the transportation $[\mathrm{CZK} / \mathrm{km}]$, considered $45 \mathrm{CZK} / \mathrm{km}-\left(\mathrm{k}_{\mathrm{E} 5}\right)$

$Q \quad$ is amount of waste $[\mathrm{t}]-\left(\mathrm{k}_{\mathrm{E} 1}\right)$

$k_{d}$ is capacity of waste transportation vehicle [t], considered maximal capacity 25 tons - $\left(\mathrm{k}_{\mathrm{E} 4}\right)$

$m$ is rate for waste manipulation, considered average price in the region $150 \mathrm{CZK} /$ ton

$p$ is the price of landfill $[\mathrm{CZK} / \mathrm{t}]$, considered average price of landfill in the region $1000 \mathrm{CZK} /$ ton

Table 3 contains results of the evaluation of $E_{E}$ by using software.

Table 3. Efficiency evaluation (economic aspect of evaluation)

\begin{tabular}{lccccc}
\hline Municipality & $\begin{array}{c}\text { Distance from } \\
\text { the facility }\end{array}$ & $\begin{array}{c}\text { Distance in the } \\
\text { municipality }\end{array}$ & $\mathrm{E}$ & $\mathrm{E}_{\mathrm{E}}=\mathrm{E} / \mathrm{C}$ & Rank \\
\hline Blansko & 32.1 & 15 & 7286.52 & 0.49 & 8. \\
Boskovice & 22.1 & 9 & 3001.36 & 0.43 & 9. \\
Brno & 0 & 35 & 202885.25 & 0.55 & 6. \\
Břeclav & 16.6 & 10 & 11037.55 & 0.60 & 5. \\
Hodonín & 18.2 & 18 & 12058.02 & 0.61 & 4. \\
Kuřim & 21.7 & 8 & 3468.59 & 0.54 & 7. \\
Kyjov & 20.8 & 9 & 6828.54 & 0.92 & 3. \\
Veselín. & 16.3 & 9 & 7967.79 & 1.11 & 1. \\
Moravou & 16.8 & 15 & 12161.45 & 0.94 & 2. \\
Vyškov & 13.5 & 20 & 10420,63 & 0.34 & 10. \\
Znojmo & & & & &
\end{tabular}

According to the results of cost-effectiveness, the best managing municipality in terms of municipal waste expenditure is Veselí nad Moravou followed by municipalities Vyškov, Kyjov and Hodonín. 


\section{Effectiveness evaluation $-\boldsymbol{E}_{E f}$}

Here we have example of effectiveness evaluation of the city of Brno.

City of Brno has in its Waste Management Plan the following objectives and performance criteria of expenditure effectiveness:

1. Increase material utilization of municipal waste to $50 \%$ by 2010 compared to year 2000 - $\mathrm{k}_{\mathrm{Enf} 1}$;

2. Material utilization of municipal waste in relation to the whole Czech Republic (ensure the collection and subsequent use or alternatively controlled disposal of hazardous components of municipal waste (50\% in 2005 and $75 \%$ in 2010)) - $\mathrm{k}_{\mathrm{Ef} 2}$;

3. Ensure recycling of construction and demolition waste (utilize $50 \%$ of the weight of emerging construction and demolition waste before end of 2005 and $75 \%$ before end of 2012) - $\mathrm{k}_{\mathrm{Ef} 3}$;

4. Prefer incineration of mixed municipal waste with energy recovery over landfill storage - $\mathrm{k}_{\mathrm{Ef} 4}$;

5. Reduce the weight ratio of landfilled waste with perspective of further reduction by $20 \%$ in 2010 compared to year $2000-\mathrm{k}_{\mathrm{Ef} 5}$;

6. Decrease the ratio of landfilled waste with potential of energy utilization (35\% in 2010) - $\mathrm{k}_{\mathrm{Ef} 6}$;

7. Decrease ratio of landfilled biodegradable municipal waste (75\% of what the production was in 1995 compared to 2010) - $\mathrm{k}_{\mathrm{Ef} 7}$;

8. Increase utilization of waste through recycling up to $55 \%$ in $2012-\mathrm{k}_{\mathrm{Ef} 8}$.

For simplification, all the criteria implemented in software were assigned the same weight $\mathrm{w}_{\mathrm{i}}=0.125$. The expert panel gave each criterion the values in Table 3 .

Table 4. Evaluation of effectiveness (city of Brno)

\begin{tabular}{lcccccccc}
\hline Criterion & $\mathrm{k}_{\mathrm{Ef} 1}$ & $\mathrm{k}_{\mathrm{Ef} 2}$ & $\mathrm{k}_{\mathrm{Ef} 3}$ & $\mathrm{k}_{\mathrm{Ef} 4}$ & $\mathrm{k}_{\mathrm{Ef} 5}$ & $\mathrm{k}_{\mathrm{Ef} 6}$ & $\mathrm{k}_{\mathrm{Ef} 7}$ & $\mathrm{k}_{\mathrm{Ef} 8}$ \\
\hline Criterion value & 0.95 & 1 & 0.86 & 1 & 0.85 & 0.95 & 0.65 & 1
\end{tabular}

Then $E K_{E f}=0.9075$.

\section{Evaluation of the quality $-E_{Q}$.}

The South Moravian Region has in its strategic document called Waste Management Plan (WMP) 25 goals related to waste management. The city of Brno put in its own Waste Management Plan 8 goals, all of which are all included in the South Moravian Region's WMP. Therefore, these criteria take value of 1 (100\% associated with the strategic documents). Considering the evaluation of quality of expenditure, it is possible to use criteria of effectiveness evaluation and build $\mathrm{E}_{\mathrm{Q}}$, when $\mathrm{E}_{\mathrm{Q}}=1$.

For the city of Brno the complex criterion for evaluation of economic efficiency comes out as follows:

$$
K_{E}=E_{E}+E_{E f}+E_{Q}=0.55+0.9075+1=2.4575
$$




\subsection{Evaluation of Environmental Aspect}

Considering waste management expenditure, criteria for evaluation of environmental efficiency could be determined as follows (all of them are maximizing):

$k_{E n 1} \quad$ Amount of municipal solid waste per capita in comparison with Czech national average (national average proportion of the municipality value);

$k_{E n 2} \quad$ Waste management expenditure per capita compared to the Czech average (ratio of Czech average to the to the actual municipality value);

In this analysis we have chosen to evaluate only sample of South Moravian Region municipalities over 10000 citizens. Experts assigned these criteria by similar weight of wi $=0.5$. Table 5 contains values calculated by software that the expert panel assigned to each criterion:

Table 5. Evaluation of environmental aspect (South Moravian Region's municipalities over 10000 citizens), year 2008

\begin{tabular}{lcccc}
\hline $\begin{array}{l}\text { Criterion/ } \\
\text { Municipality }\end{array}$ & $\mathrm{k}_{\mathrm{En} 1}$ & $\mathrm{k}_{\mathrm{En} 2}$ & $\begin{array}{c}\text { Weight } \\
\text { Sum }\end{array}$ & Rank \\
\hline Blansko & 1.033 & 1.054 & 1.044 & 3. \\
Boskovice & 1.192 & 1.081 & 1.137 & 1. \\
Brno & 1.099 & 0.741 & 0.920 & 5. \\
Břeclav & 0.851 & 0.979 & 0.915 & 6. \\
Hodonín & 0.870 & 0.844 & 0.857 & 9. \\
Kuřim & 1.152 & 0.636 & 0.894 & 7. \\
Kyjov & 0.705 & 0.997 & 0.851 & 10. \\
Veselí n. Moravou & 0.880 & 1.108 & 0.994 & 4 \\
Vyškov & 1.090 & 1.139 & 1.115 & 2. \\
Znojmo & 1.061 & 0.698 & 0.880 & 8.
\end{tabular}

According to the results in Table 5, Boskovice is the best municipality in terms of environmental efficiency, followed by Vyškov, Blansko, Veselí nad Moravou and Brno.

\subsection{Evaluation of Social Aspect}

When it comes to municipal waste management expenditure, suitable criteria for social efficiency evaluation of given calculated expenditure could be the following:

$k_{S 1} \quad$ Willingness to sort municipal waste (in percents)

$k_{S 2} \quad$ Employment - Influence on employment (is given service carried out by local company or external one, and so on) (in percents)

$k_{S 3} \quad$ Living standard of citizens - does the expenditure have positive impact on living standard of citizens of municipality (in percents)

When evaluating municipal waste management expenditure in Brno, experts gave these weights to the given criteria: $\mathrm{w}_{1}=0.4, \mathrm{w}_{2}=0.3, \mathrm{w}_{3}=0.3$. Table 6 contains calculated values assigned by experts to each criterion. 
Table 6. Evaluation of social aspect (city of Brno)

\begin{tabular}{lccc}
\hline Criterion & $\mathrm{k}_{\mathrm{S} 1}$ & $\mathrm{k}_{\mathrm{S} 2}$ & $\mathrm{k}_{\mathrm{S} 3}$ \\
\hline Criterion value & 0.58 & 0.85 & 0.86
\end{tabular}

Then $K_{S}=0.748$.

\section{Summary and Outlook}

Evaluation of the effectiveness of public environmental protection expenditure is already very complex matter $[9,10,11]$. There are many factors and indicators that affect the level of expenditure [11]. This paper discusses why the most appropriate tool seems to be the Cost-effectiveness Analysis with its application as a part of multi-criteria analysis depending on factors influencing expenditure on given environmental service. The open source software was developed to implement this tool. Determination of all these factors, as shown in the case study of South Moravia Region municipalities, is a necessary prerequisite for establishing an indicator of efficiency.

We believe that this is one of the ways to evaluate the efficiency of public spending on environmental protection with the use of developed software. At the same time we realize that the described problem is much more complicated in practice because the amount of public spending is influenced by a variety of external factors, such as performance orientation, organizational aspects, human resources, the use of information technology, political decisions, interest groups, etc. Some of these factors cannot be quantified, they can only be described.

Methodology for the efficiency evaluation of municipal environmental protection expenditure is primarily meant for municipalities and faces the following criteria:

1. the utilization of sustainable development concept;

2. the utilization of existing methodologies and analyses;

3. data availability;

4. multi-criteria evaluation with weight sums utilization;

5. simplicity together with complexity of outcome.

This methodology was implemented in open soursce application software and it has been tested on sample of 200 South Moravian Region Municipalities together with all Czech municipalities with extended powers. It has been approved and certified by Ministry of Environment of the Czech Republic in November 2010 [12]. A software [13] as a tool for evaluation has been also connected with the methodology and it is available for all municipalities of the Czech Republic.

Acknowledgements. We thank the Ministry of Environment (MoE) of the Czech Republic for the support. Paper is one of the results of the MoE of the Czech Republic project SP/4i1/54/08 „Analysis of municipal budgets efficiency in relation to the environmental protection", where we have identified that efficiency evaluation of municipal environmental expenditure is very complex and extraordinary difficult task. This paper is based on our common findings. 


\section{References}

1. EPA, An Introduction to Environmental Accounting As a Business Management Tool: Key Concepts And Terms. EPA 742-R-95-001 (1995)

2. Automated budget information system / automatizovaný rozpočtový informační systém ARIS, http: / / wwwinfo.mfcr.cz/aris /

3. Eurostat, Classification of Environmental Protection Activities and Expenditure (CEPA 2000) (2000), http: / / ec . europa . eu/eurostat/ramon/nomenclatures / index.cfm?TargetUrl=LST_NOM_DTL\&StrNom=CEPA_2000\& StrLanguageCode $=$ EN\&Int PCKey $=\&$ St $r$ LayoutCode=HIERARCHIC

4. Soukopova, J., Bakos, E.: Assessing the efficiency of municipal expenditures regarding environmental protection. In: Environmental Economics and Investment Assessment III, pp. 107-111. WIT Press, Cyprus (2010)

5. Farrell, J.: The Measurement of productive efficiency. Journal of the Royal Statistical Society, Part III 1957 120(3), 253-290 (1957)

6. Boardman, A., Cost-benefit, E.: analysis: concepts and practice, 2nd edn. Prentice Hall, Upper Saddle River (2001)

7. Levin, H., McEwan, M., Cost-effectiveness, P.J.: analysis: Methods and applications, 2nd edn. Sage Publications, Inc., Thousand Oaks (2000)

8. Raszka, J.: The CEA - a superior alternative to the cost-benefit Analysis of environmental infrastructure investments. Paper Presented at the Fifth European Conference on Evaluation of the Structural Funds, Challenge for Evaluation in an Enlarged Europe, Budapest (June 26/27, 2003)

9. García-Sánchez, I.: Efficiency measurement in Spanish local government: The case of municipal water services. Review of Policy Research 23(2), 355-371 (2006)

10. Lokkainen, H., Susiluoto, I.: Cost efficiency of Finnish municipalities 1994-2002. An application of DEA and Tobit methods. In: Paper Presented at the 44th Congress of the European Regional Science Association, Porto, Portugal, August 25-29 (2004)

11. Mandl, U., Dierx, A., Ilkowitz, F.: The effectiveness and efficiency of public spending, European Commission, Economic paper 301 (2008)

12. Soukopova, J., Neshybova, J., Bakos, E., Hrebicek, J.: Methodology for the efficiency evaluation of the municipal environmental protection expenditure no. 2437/320/109398/ENV/10 (Metodika hodnocení efektivnosti výdajů obcí na ŽP), Ministry of Environment of the Czech Republic, Praha (2010)

13. Soukopova, J., Neshybova, J.: Software for Methodology for the efficiency evaluation of the municipal environmental protection expenditure (2010),

http: / / cms. amr.webnode.cz/

metodika-hodnoceni-vydaju-obci/software-pro-hodnoceni 